\title{
Location of community pharmacies and prevalence of oral conditions in the Western Cape Province
}

\begin{tabular}{|c|c|}
\hline \multicolumn{2}{|c|}{$\begin{array}{l}\text { Authors: } \\
\text { Feroza Amien }{ }^{1} \\
\text { Neil G. Myburgh }{ }^{1} \\
\text { Nadine Butler }{ }^{2}\end{array}$} \\
\hline \multicolumn{2}{|c|}{$\begin{array}{l}\text { Affiliations: } \\
{ }^{1} \text { Faculty of Dentistry, } \\
\text { University of the Western } \\
\text { Cape, South Africa }\end{array}$} \\
\hline \multicolumn{2}{|c|}{$\begin{array}{l}{ }^{2} \text { School of Pharmacy, } \\
\text { University of the Western } \\
\text { Cape, South Africa }\end{array}$} \\
\hline \multicolumn{2}{|c|}{$\begin{array}{l}\text { Correspondence to: } \\
\text { Feroza Amien }\end{array}$} \\
\hline \multicolumn{2}{|c|}{$\begin{array}{l}\text { Email: } \\
\text { feroza.amien@uct.ac.za }\end{array}$} \\
\hline \multicolumn{2}{|c|}{$\begin{array}{l}\text { Postal address: } \\
\text { School of Public Health } \\
\text { and Family Medicine, } \\
\text { University of Cape Town, } \\
\text { Anzio Road, Observatory } \\
7925 \text {, South Africa }\end{array}$} \\
\hline \multicolumn{2}{|c|}{$\begin{array}{l}\text { Dates: } \\
\text { Received: } 10 \text { July } 2012 \\
\text { Accepted: } 26 \text { Apr. } 2013 \\
\text { Published: } 13 \text { Aug. } 2013\end{array}$} \\
\hline \multicolumn{2}{|c|}{$\begin{array}{l}\text { How to cite this article: } \\
\text { Amien, F., Myburgh, N.G. \& } \\
\text { Butler, N., 2013, 'Location } \\
\text { of community pharmacies } \\
\text { and prevalence of oral } \\
\text { conditions in the Western } \\
\text { Cape Province', Health SA } \\
\text { Gesondheid 18(1), Art. \#687, } \\
9 \text { pages. http://dx.doi.org/ } \\
10.4102 / \text { hsag.v18i1.687 }\end{array}$} \\
\hline \multicolumn{2}{|c|}{$\begin{array}{l}\text { Copyright: } \\
\text { (C) 2013. The Authors. } \\
\text { Licensee: AOSIS } \\
\text { OpenJournals. This wo } \\
\text { is licensed under the } \\
\text { Creative Commons } \\
\text { Attribution License. }\end{array}$} \\
\hline \multicolumn{2}{|l|}{ Read online: } \\
\hline 口舟安 & $\begin{array}{l}\text { Scan this QR } \\
\text { code with your } \\
\text { smart phone or } \\
\text { mobile device } \\
\text { to read online. }\end{array}$ \\
\hline
\end{tabular}

Community pharmacists are approached regularly for oral health advice; most commonly for ulcers which could be indicative of oral cancer, HIV, and various systemic diseases. Community pharmacists should know how to manage these conditions yet they have very limited training to manage these conditions appropriately. The area location and socioeconomic status (SES) of the pharmacy should be considered as it may influence patient management. A study of this nature has not yet been conducted in the Western Cape Province of South Africa. To determine the prevalence and frequency of oral complaints at community pharmacies and if these parameters differ by metropolitan location and SES. A cross-sectional survey of 162 randomlyselected private sector pharmacies was conducted. The sample $(n=121)$ was stratified by SES and metropolitan location. An open-ended structured questionnaire was faxed to pharmacists. A telephonic interview was conducted a day later. Community pharmacists were asked about the frequency and type of oral health problems they encountered. Most pharmacists (91\%) dealt with oral health problems frequently, most commonly for ulcers (55.8\%), thrush $(49.2 \%)$, and toothache $(33.3 \%)$. The results did not differ by metropolitan location and SES (Chi-squared, Fisher's Exact, $p>0.05$ ), with the exception of toothache and mouth sores. Community pharmacists are an important part of an interdisciplinary team, and play a definite role in the early detection of oral health conditions, namely, caries, HIV and oral cancer. Training on common oral health conditions should be included in undergraduate pharmacy curricula and continuous professional development courses.

Gemeenskapsaptekers word gereeld genader vir advies rakende mondgesondheid, hoofsaaklik mondsere wat ' $n$ aanduiding kan wees van mondkanker, MIV en verskeie sistemiese siektes. Gemeenskapsaptekers moet weet hoe om hierdie kwessies te hanteer. Die ligging van die area en die sosio-ekonomiese status (SES) van die apteek moet in ag geneem word aangesien dit 'n invloed mag hê op die hantering van die pasiënt. 'n Studie van hierdie aard is nog nie in die Wes-Kaap Provinsie van Suid-Afrika onderneem nie. Die doel van hierdie studie is om die voorkoms en herhaling van klagtes oor mondsiektes by gemeenskapsapteke te bepaal en of hierdie parameters verskil na gelang van metropolitaanse ligging en SES. 'n Deursneeopname van 162 ewekansig geselekteerde privaat sektor-apteke is onderneem. Die steekproef $(n=121)$ is gestratifiseer ten opsigte van SES en metropolitaanse ligging. 'n Oopeinde gestruktureerde vraelys is aan apteke gefaks. 'n Telefoniese onderhoud is 'n dag later gevoer. Gemeenskapsaptekers is gevra na die herhaling van en die tipe mondgesondheidsprobleme wat hulle teëgekom het. Die meeste aptekers (91\%) het dikwels met mondprobleme te doen gekry, meestal mondsere (55.8\%), mondsproei (49.2\%) en tandpyn (33.3\%). Die bevindinge het nie verskil na gelang van metropolitaanse ligging en SES (Chi-kwadraat, Fisher se eksakte toets, $p>0.05$ ) nie, met die uitsondering van tandpyn en mondsere. Gemeenskapsaptekers vorm 'n belangrike deel van 'n interdissiplinêre span, en speel 'n definitiewe rol in die vroeë opsporing van mondgesondheidstoestande, naamlik tandverrotting, MIV en mondkanker. Opleiding in algemene mondgesondheidstoestande behoort deel te vorm van voorgraadse aptekerskurrikulums en voortgesette professionele ontwikkelingskursusse.

\section{Introduction}

\section{Problem statement}

Over the years, the role of the community pharmacist has expanded from being primarily that of a drug dispenser, to that of a health professional who is active in general health promotion and education (Beney, Bero \& Bond 2000; Lombard 1991:80) with a patient-orientated approach (Gilbert 1998a:280). This paper explores whether pharmacists have a role to play in oral health prevention, as has been alluded to in some studies (Dickinson, Howlett \& Bulman 1995:235; Gilbert 1998b:439; Maunder \& Landes 2005:219; Priya et al. 2008:104). None of these studies, however, were conducted in the context of the Western Cape Province of South Africa. Only one study of this nature was conducted in South Africa (in Gauteng Province), but it was a long time ago (Gilbert 
1998b). Oral lesions may be indicative of serious underlying conditions; however, because of the seemingly benign nature of some of these lesions, for example oral ulcers and oral thrush, people may bypass a dentist or doctor and present to a pharmacist instead for symptomatic relief. Pharmacists are therefore in a good position to detect underlying conditions through the presentation of oral lesions. According to Butler, a professor of Pharmacy Practice at the School of Pharmacy at the University of the Western Cape, pharmacists have very limited training in oral healthcare problems (Prof. N. Butler [pers. comm.], 02 Feb 2006). It is therefore imperative to ascertain how often pharmacists encounter patients with oral health complaints and what the most common complaints are. The location of the pharmacy may influence the type of patient management provided by pharmacists (Rogers et al. 1998:365), so this paper also explores whether the location of the pharmacy, in terms of socioeconomic status (SES) and metropolitan location, exerts an influence on patients' oral health-seeking behaviour in pharmacies.

\section{Literature review}

Ambler (1996), a past president of the South African Association of Community Pharmacists, referred to the expanded role of the pharmacist as:

A role ... which enhances clinical skills and is vitally necessary, and one which should not enable him to be a barefoot doctor, but rather allow him to make an educated assessment of when a patient needs to be referred to a doctor. He needs to know what he doesn't know. He needs to know where his sphere of responsibility ends and where someone else's starts. (p. 299)

This statement highlights the community pharmacist's role in the referral of patients to other health professionals. It also places them firmly within the Primary Healthcare approach as they can offer preventive services that may enable them to detect abnormalities even before signs and symptoms of a disease manifest (Gilbert 1998b:439; Lombard 1991:80). This expanded role of pharmacists has led to an extended definition which encompasses their role as community pharmacists. For the sake of brevity, the term 'pharmacist' will be used throughout the document.

Pharmacists have a long history of being health advisors to the public (Gilbert 1998c:153). It has also been shown that pharmacies tend to have a high level of utilisation (Gilbert 1998c:157), as they see many patients and are often approached for advice regarding ailments as well as for advice with regard to self-medication. A study of 53 community pharmacies in Johannesburg, South Africa, demonstrated that a substantial number of patients go to pharmacies without a doctor's prescription, with the intention of seeking advice from the pharmacist (Gilbert 1997:101). Sello et al. (2012) conducted a study amongst 2013 participants in four townships in the West Rand District of Gauteng Province, South Africa. About a quarter of the participants (26.5\%) reported that their first choice of healthcare provider is a pharmacist. More than one-third (37\%) of the respondents indicated that the pharmacist was their first choice of healthcare provider in the case of an emergency.
Pharmacists are easily accessible as there are no appointments required or long queues to contend with (Gilbert 1998b:440; Lombard 1991:79) and, until 2007, there were no direct charges for advice given. Since 2007, pharmacists have been allowed to levy a professional fee for services rendered (South African Pharmacy Council 2012), which may still be cheaper than consulting a medical doctor (Gilbert 1997:101).

Pharmacists and their staff are well placed to offer advice on oral health (Chestnutt, Taylor \& Mallinson 1998:533). However, few studies have actually explored the role of the pharmacist as an advisor on oral health. These studies were conducted in North England (Maunder \& Landes 2005); the United Kingdom (UK) (Dickinson et al. 1995); Chennai, India (Priya et al. 2008) and in Johannesburg, South Africa (Gilbert 1998b). Each of these studies concluded that community pharmacists are approached for advice on oral health matters on a regular basis (more than once a week). The literature demonstrates that the most common advice sought in all of the above-mentioned studies was for (listed in order of descending prevalence) (1) oral ulcers (20\%-93\%); (2) toothache $(18 \%-88 \%)$; (3) bleeding gums $(4 \%-84.4 \%)$; and (4) loose dentures $(1 \%-48.5 \%)$. The only exception to this is in Chennai, where toothache was the most common oral complaint encountered followed by gum problems such as bleeding gums and/or halitosis and oral ulcers (Priya et al. 2008:107). In all of the above-mentioned studies, advice was less-commonly sought for teething, choice of mouth rinses, fluoride supplements, toothbrush and toothpaste. None of these studies assessed whether the locational context of the pharmacy could have influenced the oral health-seeking behaviour of their patients.

There are many variables that could influence access to pharmacies, such as gender, age, family income and the educational level of community residents (Sello et al. 2012:1). Conversely, the area location of the pharmacy and SES thereof, may influence pharmacists' management of their patients (Rogers et al. 1998:365). Rogers et al. (1998:365) conducted a study in North West England to determine how the locational context of a pharmacy might influence the nature and quality of advice-giving by pharmacists. They reported that locality (designated as rural, suburban, inner city, small and large town) does indeed influence and shape the activities and advice-giving potential of pharmacists. The authors concluded that some of the differences in advice-giving in the different pharmacy locations related in part to the SES of the populations using the pharmacy, as well as the available amenities in the area. This particular study suggested that:

an inverse care law may be operating in relation to the use of community pharmacy, with people in areas with the greatest health need seemingly receiving a poorer quality service than those using pharmacies in more affluent areas (Rogers et al. 1998:373).

International research has shown that people living in relatively lower SES areas are more likely to suffer from caries, advanced periodontal disease, oral cancer and HIV (Amien et al. 2004; Hobdell et al. 2003:91; Tladi 2006:369). This differential profile of disease prevalence in lower socioeconomic areas influences directly the type of help and advice sought in these areas. 


\section{Research objectives}

The objectives of this study were to determine how often pharmacists are approached by patients seeking advice on oral health problems (i.e. frequency of oral health complaints), the prevalence of the most common oral health problems encountered by pharmacists (i.e. the most common types of oral health complaints encountered) and to assess the influence of metropolitan location and SES on the frequency and prevalence of oral healthcare problems encountered in the community pharmacy in the Western Cape Province of South Africa.

\section{Significance of work}

This study highlights the importance of a multidisciplinary approach to disease prevention as it demonstrates the very important role that pharmacists have to play in the detection and management of oral health conditions. Pharmacists in the Western Cape Province of South Africa encounter oral health complaints frequently, the most common of which are oral ulcers and oral thrush. These lesions indicate most commonly a range of benign conditions, such as localised trauma in the case of oral ulcers and antibiotic use in the case of oral thrush. However, oral ulcers and oral thrush can also be indicative of more serious diseases such as oral cancer, HIV and other systemic diseases. In fact, pharmacies may serve as a reservoir of undiagnosed cases of HIV as oral lesions may be the first presenting sign of HIV (Arendorf \& Holmes 1999:631).

The results of this study may imply that pharmacists are well placed within the healthcare profession for the early detection of very serious illnesses via the oral manifestations of these conditions.

\section{Research method and design Study design and sampling}

A cross-sectional survey was conducted with community pharmacists in the Western Cape Province. A stratified random sample of pharmacies in the Western Cape Province was drawn from a complete list of pharmacies, obtained from the South African Pharmacy Council. A computerised random-number generator was used to draw the sample. A sample size calculation was conducted in the Statcalc function of EpiInfo version 6, which yielded a minimum sample size of 79 pharmacies; however 162 pharmacies were selected in order to compensate for non-responders.

\section{Stratification of pharmacies}

The sample of pharmacies was stratified by the relative SES (high and low), as well as by metropolitan or non-metropolitan locations (metro and non-metro respectively) to yield the following four categories (Table 1):

1. High socioeconomic metro (pharmacies in a high socioeconomic metropolitan area).

2. Low socioeconomic metro (pharmacies in a low socioeconomic metropolitan area).
TABLE 1: Stratification of area location of pharmacies.

\begin{tabular}{lllll}
\hline $\begin{array}{l}\text { Metropolitan } \\
\text { location }\end{array}$ & $\begin{array}{l}\text { Median } \\
\text { income }\end{array}$ & $\begin{array}{l}\text { Income } \\
\text { level }\end{array}$ & $\begin{array}{l}\text { Area and income } \\
\text { level }\end{array}$ & $\begin{array}{l}\text { Median income } \\
\text { for entire sample }\end{array}$ \\
\hline Metro & $>$ R149 191 & High & $\begin{array}{l}\text { Metro high SES } \\
(n=30)\end{array}$ & R92 777 \\
Metro & $<$ R149 191 & Low & $\begin{array}{l}\text { Metro low SES } \\
(n=30)\end{array}$ & - \\
Non-metro & $>$ R63 223 & High & $\begin{array}{l}\text { Non-metro high SES } \\
(n=30)\end{array}$ & - \\
Non-metro & $<$ R63 223 & Low & $\begin{array}{l}\text { Non-metro low SES } \\
(n=31)\end{array}$ & - \\
\hline
\end{tabular}

Source: Authors' own construction

$\mathrm{SES}$, socioeconomic status.

3. High socioeconomic non-metro (pharmacies in a high socioeconomic non-metropolitan area).

4. Low socioeconomic non-metro (pharmacies in a low socioeconomic non-metropolitan area).

The rationale for stratifying by SES and metropolitan location was to minimise the chances of confounding the results. Studies have shown that these variables could influence the nature and type of advice sought by patients and provided by pharmacists (Cohen \& Manski 2006:556; Rogers et al. 1998:365) and that the relative SES of the area in which the pharmacy is located should serve as a proxy of the SES of the clientele the pharmacy serves (Domínguez-Berjón et al. 2006:54).

Stratification was achieved, firstly, by obtaining a complete list of pharmacies in the Western Cape Province, as well as through a commercially-available dataset (Eighty20 2006) that consisted of the average annual household income data of the Western Cape Province for 2006. Annual household income was the SES indicator of choice as its an economic indicator and has been applied successfully in other studies (Bhorat \& Sheikh 2004; Hirschowitz 2000; Lalloo et al. 2004; McDonald, Piesse \& Van Zyl 2000; Myburgh et al. 2005). It is also appropriate in the South African context because South African households seem to have an economic culture of pooling their financial resources (Berzborn 2007:675; Case 2001:289).

The dataset from Eighty20 was used to determine the weightedaverage annual household income of each residential area in the Western Cape Province. The dataset consisted of a list of each area in the Western Cape Province, with a corresponding list of various income ranges and the respective frequencies thereof for each residential area. The weighted-average income was calculated by first determining the midpoint of each income range and then using the SUMPRODUCT function in Excel version 11, which is based on the following calculation (Keller \& Warrack 2000):

\section{$\sum$ a-1 Midpoint of income range $X$ frequency Sum of all frequencies}

The residential areas were then ranked (in ascending order) according to the weighted averages. Median household income was then calculated based on the weighted-average annual household income in each area in order to determine whether a residential area in a metropolitan and nonmetropolitan location was in a relatively low or high SES area. The designation of pharmacies serving communities with a relatively high SES was determined by the top $50 \%$ ranked household income levels for each area. 
The median annual household incomes of the metropolitan and non-metropolitan locations are outlined in Table 1. The single median of the annual household income for 2006 was R92 777, which value was used as a threshold for relative 'high' and 'low' SES. This amount was not used to stratify by SES as it only rendered pharmacies in three categories, namely, metro high SES, metro low SES and non-metro low SES. This method would have excluded any stratification by non-metro high SES. Therefore, separate medians were calculated for metro (R149 191) and non-metro (R63 233) areas.

\section{Data collection methods and instrument design}

The data was collected by means of a structured questionnaire. Telephonic interviews were conducted by the researcher, who is a dentist, as it was a quicker and more convenient method of acquiring information from a sample that was meant to represent the Western Cape Province. Resource constraints prevented data collection by someone other than the researcher. Ideally, non-dental personnel should have collected the data in order to prevent obsequiousness bias. The literature shows that attempts at obtaining good response rates with community pharmacists included informing potential respondents about the study prior to data collection, sometimes telephonically; and conducting a telephonic interview after pharmacists have received a premailed questionnaire (Smith 2002:22). In general, response rates were higher with telephonic interviews than mailed interviews (Smith 2002:23). The method of data collection in this study was based on these findings. The questionnaire was faxed to the pharmacy 24 hours prior to the telephonic interview so that the pharmacist that would be interviewed could familiarise him- or herself with the questionnaire. Pharmacists were telephoned after the questionnaire was faxed, in order to obtain verbal informed consent to participate in the study and also to confirm a convenient time to conduct the interview. If more than one pharmacist worked at a particular pharmacy, the researcher spoke to the pharmacist who was available at the time and set up an interview with that particular pharmacist. Pharmacists were asked the following two questions:

1. How often do customers present with mouth problems? (They could tick only one of the following answer options: nearly every day, more than once a week, less than once a week, once a month, or hardly ever).

2. What are the most common oral health problems that customers present with? (This was an open-ended question so as not to lead the participant).

\section{Data analysis}

The data was captured in Excel version 11 and analysed using EpiInfo version 13. Variables were described in detail, using means and standard deviations. Chi-squared $\left(\chi^{2}\right)$ tests were used to determine if there was a significant difference between categorical variables. The Fisher's Exact test was conducted if the numbers were insufficient to conduct Chisquared tests, or if the data was not normally distributed. The analysis of variance test (ANOVA) was used to determine if there was a difference between means. A 95\% significance level was used, therefore all test results with a $p$-value less than 0.05 were considered to be statistically significant. The relative risk (RR) was also assessed for significance. An RR of ' 1 ' indicates that there is no difference between the exposure and outcome. An RR of $>1$ indicates that the exposure is a risk factor, whereas an $R R$ of $<1$ indicates a protective factor. If the confidence interval of the RR contained a value of ' 1 ', then the RR was not considered to be statistically significant. Tests for practical significance were conducted on variables which displayed statistically-significant differences, using the Pi $(\Phi)$ test for categorical data $\left(\Phi=\sqrt{\chi^{2}} / N\right.$, where $N$ is the sample size). The Pi value ranges of $0.10-0.29 ; 0.30-0.49 ;>0.5$ represent minimal, typical and substantial relationships, respectively, between two variables (Vaske, Gliner \& Morgan 2002:291).

\section{Results}

\section{Sample description}

Of the 162 pharmacists invited to participate in this study, 121 agreed to participate, yielding a response rate of $75 \%$. The sample consisted mainly of men $(67.2 \%)$. The mean age of all pharmacists was $43.9 \pm 10.5$ years (median $=44$ years). Almost all of the pharmacists (98\%) interviewed were principal or responsible pharmacists, whilst only two pharmacists were locums. None of the participants were pharmacist interns.

There was an equal distribution of pharmacists in each category of metro high SES, metro low SES, non-metro high SES ( $n=30$ in each) and non-metro low SES $(n=31)$, as well as between metro and non-metro areas (60 and 61 pharmacists respectively). Overall, $65.3 \%(n=79)$ of pharmacies were in a low-income area (i.e. median household income per annum was < R92 777). The median annual household income in terms of metro or non-metro and SES denominations was significantly different (R149 $191 \pm$ R79 465 vs. R63 $223 \pm$ R13 537; Kruskal-Wallis $=70.3, \mathrm{df}=1, p<0.001)$ (Table 1).

\section{Frequency of oral complaints encountered by pharmacists}

Almost two-thirds of pharmacists $(n=76)$ were confronted with oral health problems nearly every day and almost a third $(n=30)$ dealt with these more than once a week. When these results were combined into two categories, namely frequent and infrequent attendance, most pharmacists (91\%, $n=110$ ) dealt with oral health problems frequently (where frequent attendance refers to pharmacists who indicated that they deal with oral health problems nearly every day or more than once a week; and infrequent attendance refers to pharmacists who indicated that they deal with oral health problems less than once a week or hardly ever).

The frequency with which patients presented to pharmacists with oral health problems did not differ significantly between SES (Fisher's Exact, $p=0.40 ; \mathrm{RR}=1.03$ [1.0-1.1]) and metropolitan location (Fisher's Exact, $p=0.1 ; \mathrm{RR}=1.1$ [1.0-1.2]). 


\section{Prevalence of oral complaints encountered by pharmacists}

The most common oral health problems encountered by pharmacists were oral ulcers, oral thrush and toothache, respectively (Table 2). About $15.8 \%(n=19)$ of pharmacists mentioned various oral conditions that were not commonly seen at most of the pharmacies, such as halitosis, 'bad oral health', tonsillitis and a sore or burning tongue, amongst others. These lesions were grouped under 'other' (Table 2). The prevalence of most of the oral health problems encountered by pharmacists did not differ by metropolitan location, with the exception of toothache (Chi-squared $=5.91 ; p=0.02$; $\mathrm{RR}=0.7$ [0.6-0.9]; $\Phi=0.22$ ) and mouth sores (Fisher's Exact, $p=0.01 ; \mathrm{RR}=1.2[1.03-1.3] ; \Phi=0.22)$. None of the oral problems encountered by pharmacists differed in prevalence in terms of the SES or the pharmacy location (Table 2).

\section{Ethical considerations}

This study was approved by the Ethical and Research Committee of the University of the Western Cape. Participants were informed about the nature of the study and the main aim of the study. Informed consent was obtained prior to the telephonic interview and noted on the researcher's questionnaire. Participants were made aware that their participation in this study would be on a voluntary basis, that they could enter the study of their own free will and that they could withdraw at any time. Confidentiality was ensured to protect the identities of the participants, as only the researcher would know which pharmacies and pharmacists were included in the study. Participants' names were noted on the researcher's questionnaire, but they were not included in the data set.

\section{Validity and reliability}

Various steps were taken to ensure the reliability and validity of this study.

A pilot study was conducted on 10 pharmacists - five in each in of the metro and non-metro areas - in order to test the methodology, whereafter appropriate changes were made to the questionnaire. The changes made were mainly in the domain of clarification of questions and the phrasing thereof in order to reduce subject variation and intra-observer variation (Katzenellenbogen \& Joubert 2007:119). The 10 pharmacists that participated in the pilot study were excluded from the main study. In order to minimise response bias, questions were mainly open-ended so as not to lead the participants.

The response rate was good, possibly because certain measures were taken in order to increase the response rate. Phone calls to pharmacists during relatively busy periods were avoided, such as month-end periods (25th - 2nd days of the month), pension day, Saturday mornings and between five and six o'clock in the afternoon during weekdays. In addition to this, various methods were employed to increase the likelihood of a response by the pharmacist, such as faxing the questionnaire prior to the interview and obtaining verbal consent telephonically (Smith 2002:22-23).

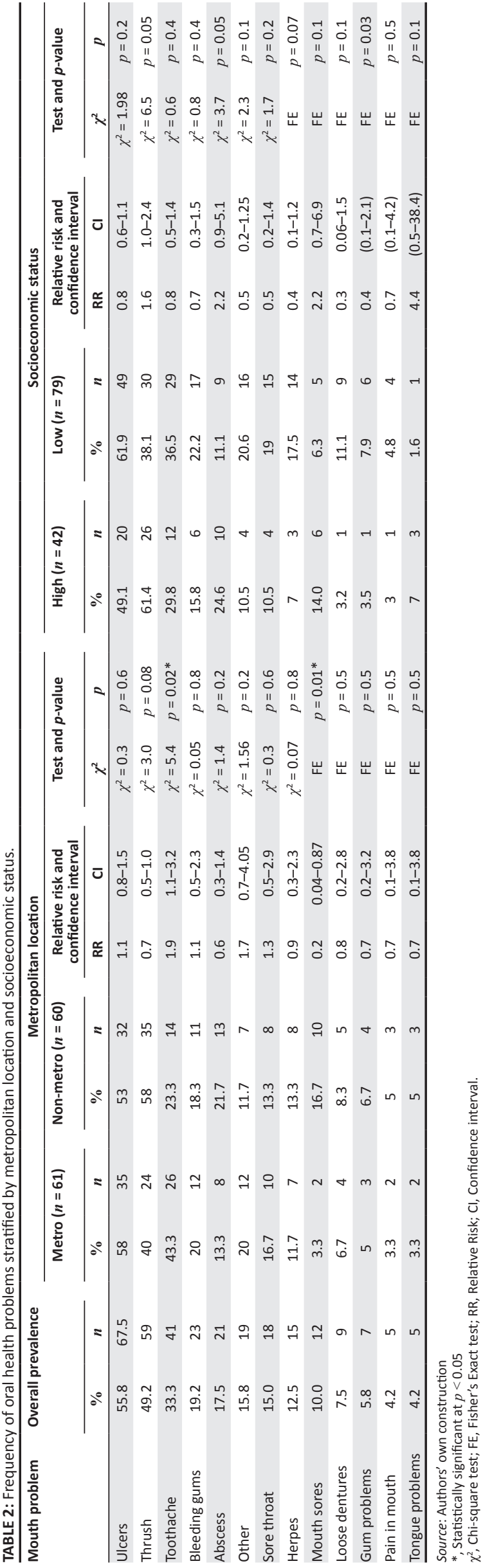


These strengths described above ensure that the results of this study are applicable to the rest of the Western Cape Province. However, the results cannot be extrapolated to the rest of the country, for several reasons. There are various factors that could influence the utilisation of pharmacies, such as the age, ethnicity and gender of the pharmacist (Sello et al. 2012:1) as well as the area location of the pharmacy (Rogers et al. 1998:365). Only the latter was controlled for in this study. The profile of community pharmacists in the Western Cape Province is generally different to the national profile, in that the average age is higher and the Western Cape Province has the secondhighest number of community pharmacists $(17 \%)$ in the country. With the exception of Gauteng and KwaZulu-Natal Provinces (which are home to $40 \%$ and $14 \%$ of community pharmacists respectively), the rest of the provinces each have less than $8 \%$ of the community pharmacists in South Africa. The gender distribution of pharmacists in this study differs from the national profile (the former has a higher prevalence of men, whereas nationally there is a predominance of female pharmacists [59\%]). In addition, access to doctors, dentists and pharmacists differ by province with a positive bias toward the Western Cape Province (Western Cape Provincial Health Consultative Workshop Report 2010:18). This, in turn, would influence differential patient access patterns for these health professionals.

\section{Discussion}

The response rate of $75 \%$ in this study is acceptable considering that the response rates usually achieved in published survey research amongst community pharmacists range between $20 \%-90 \%$. Only a third of these studies had a response rate of more than $70 \%$ (Smith 2002:25). The fact that none of the respondents were pharmacy interns increased the validity of the study because this category of staff is usually inexperienced and much less likely to have encountered oral health problems in their short-lived pharmacy careers. Their responses would have been biased toward a lower prevalence of oral health problems encountered in community pharmacies, thereby devaluing the role that pharmacists should play in the management of oral conditions.

The results of this study have reinforced the idea of pharmacists as oral healthcare advisors to the public, as most pharmacists dealt with oral health problems frequently. This finding is consistent with other studies conducted in South Africa (Gilbert 1998b:441), India (Priya et al. 2008:108), Northern England (Maunder \& Landes 2005:220) and elsewhere in the UK (Dickinson et al. 1995:235).

\section{Oral ulcers}

Another finding consistent with the literature is that more than half of the pharmacists reported that oral ulcers were the most common oral problem that they encountered (Dickinson et al. 1995:236; Gilbert 1998b:442; Maunder and Laundes 2005:220). According to Scully and Felix (2005:260), most oral ulcers are a result of local causes such as trauma or burns, but recurrent aphthous stomatitis (RAS) and oral cancer must always be considered. RAS is a very common condition (20\% prevalence) which presents with multiple, recurrent, round or ovoid oral ulcers. RAS could be indicative of serious conditions such as sexually-transmitted infections (STIs) - including HIV - as well as oral cancer. It could also be indicative of a host of systemic diseases including haematological deficiencies, gastrointestinal enteropathy, dermatological conditions and connective tissue disorders (Scully \& Felix 2005:261). It is, therefore, imperative that pharmacists are aware of this and should be trained to detect and manage these lesions appropriately, by taking a proper history, providing appropriate symptomatic relief for the problem and referring where necessary.

\section{Oral thrush}

The prevalence of oral thrush in pharmacies in South Africa is vastly different to that reported in the literature. Approximately half of the pharmacists in this study reported that they encountered oral thrush regularly. With the exception of the UK study in 1995, which reported a prevalence of 1\% (Dickinson et al. 1995:236), most of the studies that are referred to in the introduction of this paper did not even mention oral thrush when asked about the prevalence of oral conditions. So it may be reasonable to assume that pharmacists in these countries do not or seldom encounter patients with oral thrush. This could indicate different health-seeking behaviours for oral thrush in South Africa and the UK with more people in the UK attending dental or medical practices instead of community pharmacies for the treatment thereof. Alternatively, pharmacists in South Africa may encounter oral thrush more often because the prevalence may be higher than in the UK. Further research in this area is needed in order to confirm the above.

The difference in the prevalence of oral thrush in community pharmacies may also be due to variations in the prevalence of oral thrush in South Africa and the UK. Comparative data on the prevalence of oral thrush in these countries are not readily available in the literature. However, fungal infections have recently shown an important increase in incidence because the general population is more exposed to factors that favour such infections (López-Martínez 2010:179), thus the prevalence of the predisposing factors of oral thrush could be used to postulate which country has a higher prevalence thereof. A comparison of all the numerous predisposing factors of oral thrush is beyond the scope of this paper, most notably with regard to the usage of medications that decrease salivary flow and host immunity. There are simply too many medications to mention and compare. However, a comparison of some of the most common predisposing factors may provide a reasonable proxy for the comparative prevalence of oral thrush between South Africa and the UK. The most common predisposing factors for oral thrush are antibiotic therapy, corticosteroid treatment, dentures, cancer, radiation therapy, HIV (López-Martínez 2010:178), diabetes and malnutrition (Akpan \& Morgan 2002:457). Unfortunately, valid and comparable data on antibiotic and corticosteroid treatment are not readily available and hence comparisons in prevalence between South Africa and the UK 
could not be made with regard to these factors. However, data were available for all the other common predisposing factors mentioned above.

\section{Predisposing factors}

The prevalence of some predisposing factors is approximately the same in both countries, such as diabetes mellitus $(4.9 \%$ in the UK vs. 4.5\% in SA) (Bradshaw et al. 2007:703; Shaw, Sicree \& Zimmet 2010); whereas others are marginally higher in the UK. Examples of the latter include cancer (3 times higher in the UK) (Office for National Statistics 2012:3) and asthma (7 times higher in the UK) (Health Systems Trust 2007; Simpson \& Sheikh 2010:104). On the other hand, the prevalence of edentulousness (which is a useful proxy for denture wearers) is marginally higher in SA (9\%) (Ayo-Yusuf \& Ayo-Yusuf 2008:381) as opposed to the UK (6\%) (NHS Information Centre, Dental and Eye Care Team 2010:4). However, the prevalence of malnutrition and HIV is phenomenally higher in South Africa. The prevalence of malnutrition in the UK is 5\% (Russell \& Elia 2008). An absolute comparable prevalence of malnutrition is not available for South Africa; however the prevalence of obesity and underweight persons can be used for the purposes of comparison as both measurements are used to classify malnourishment (World Hunger 2012). In South Africa, the prevalence of obesity is $27.5 \%$ and $21 \%$ in women and men respectively and the prevalence of underweight persons is $6 \%$ and $12.5 \%$ in women and men respectively (Department of Health, Medical Research Council \& OrcMacro 2007:276-277). Finally, the prevalence of HIV in South Africa (5.6 million people) (UNAIDS 2011:7) is a staggering 61 times higher than in the UK (91 500 people) (Health Protection Agency 2011:5). In summary, there are marginal differences in the prevalence of common predisposing factors to oral thrush between SA and the UK, with the exception of malnutrition and HIV. Oral lesions are highly prevalent in HIV-positive individuals, the most common of which is oral thrush (Arendorf \& Holmes 1999:633). The substantially-higher prevalence of malnutrition and HIV may indicate a higher prevalence of oral thrush in South Africa, which may explain why South African pharmacists encounter more cases of oral thrush. However, further research is needed to confirm this theory.

In addition to oral thrush, oral ulcers could also be indicative of HIV infection (Arendorf et al. 1999:602). In fact, oral thrush could very well be the first sign of HIV infection (Arendorf $e t$ al. 1999:603). About 40\% - 90\% of HIV patients will present with an oral manifestation of the disease at least once in their lifetime, the most common of which is oral thrush, both locally and internationally (Arendorf \& Holmes 1999:633). Therefore, pharmacies in the Western Cape Province may serve as a reservoir of undetected cases of HIV and other STIs because patients present regularly with oral problems, the most common of which are ulcers and oral thrush. Studies have already suggested that pharmacists play a role in preventing the transmission of HIV (Ward et al. 2003:609; Watson, Bond \& Gault 2003:16). In South Africa, Ward et al. (2003) demonstrated that pharmacists were treating STIs outside of their scope of practice and therefore recommended that pharmacists could be more effective in preventing HIV transmission if they were trained adequately and their scope of practice enhanced to include syndromic treatment of STIs. Similarly, many pharmacists encounter oral healthcare problems, most commonly oral ulcers and thrush, and are treating these patients with very limited training in oral healthcare problems (Prof N. Butler [pers. comm.], 02 Feb 2006). Pharmacists are trained to perform HIV tests and provide counselling, therefore, it should not be too unrealistic to suggest that pharmacists should play a role in the detection of HIV through the recognition and response to the presentation of oral lesions associated with this disease. It seems that so far no studies have explored this avenue with regard to addressing HIV.

\section{Toothache}

The third most common oral problem encountered was toothache (33\%) and many pharmacists (17\%) also encountered an abscess in the oral cavity, which is usually a result of advanced untreated caries. Bleeding gums, which are a common symptom of gingivitis, were also encountered commonly. If this condition is left untreated it could progress to periodontitis, a condition where the inflammation has advanced from the gingivae to the surrounding tissues. Severe cases will manifest with pain and tooth loss (Lang, Schätzle \& Loë 2009:4). Caries is highly prevalent in South Africa, especially untreated caries (Van Wyk \& Van Wyk 2004:373), that would undoubtedly cause toothache at some point. It seems that many patients are presenting to the pharmacist for symptomatic treatment of caries and gingivitis before they seek curative treatment from a dentist, indicating that the pharmacist could play a role in oral health education to prevent future occurrence of caries and periodontitis.

\section{Other factors}

The location of the pharmacy had no bearing on the frequency of complaints about oral health encountered by pharmacists, so educational interventions for pharmacists should perhaps be applied homogenously to all areas, regardless of the SES or metropolitan location of the pharmacist.

The prevalence of oral lesions did not differ in any statisticallysignificantly manner, either by SES or metropolitan location, with the exception of mouth sores and toothache in the latter group (Table 2). There is no comparative data on the prevalence of mouth sores in the literature, probably because it is a colloquial term. The differential prevalence of toothache was inconsistent because, in this study, a nonmetropolitan area could serve as a proxy for a relatively low SES area as the median-weighted annual household income was significantly less in non-metropolitan areas than in metropolitan areas (Table 1). On the contrary, this study indicated that more pharmacists in metropolitan locations encountered patients with toothache. The literature, on the other hand, has consistently demonstrated that toothache is significantly more prevalent in less affluent populations in the South African context (Chankanka et al. 2011:289; 
Ferro et al. 2012:46; Hobdell et al. 2003:91; Lu et al. 2011:352). This inconsistent finding with a low practical significance, together with the fact that most of the oral lesions were encountered more-or-less equally by pharmacists, regardless of their location, suggests that the SES of the clientele may not correlate with the SES of the area of the pharmacy in the context of the Western Cape Province in South Africa, as has been suggested in another study (DomínguezBerjón et al. 2006:54). People from low SES areas could be using pharmacies in high SES areas and vice versa, as it is a common occurrence for people to visit a pharmacy that is not in their residential area. The dynamic movement of people across high and low SES areas could have blurred the socioeconomic border distinction of the residential areas in this study. The indistinct nature of the socioeconomic border could also be due to the SES indicator that was used in this study. Because SES is a relative measure, the use of any other indicator would have been just as likely to introduce this kind of misclassification.

\section{Limitations of this study}

All research studies are bound by varying degrees of limitations and this study is no different. The choice of the SES indicator may have imparted certain limitations to this study because very different conclusions can be reached about the same issue depending on the socioeconomic indicator used (Lindelow 2006:263). The use of household income in this study may have impacted on the sampling procedure due to misclassification into high and low SES areas. However, as SES is a relative measure, any SES indicator (such as personal income, family income and so forth) would have suffered the same fate.

The methods used in this study may raise some issues with regard to validity. Even though stringent attempts were made to ensure that pharmacists answered the questions truthfully, this could never be guaranteed. Some pharmacists may have fallen prey to obsequiousness bias because the interviewer was a dentist.

\section{Recommendations}

This study demonstrates that pharmacists have an important role to play in the detection and management of many systemic diseases through the correct management and recognition of oral conditions. Pharmacists need to be trained accordingly and this training should become mandatory for pharmacy undergraduates. Continuous professional development courses for pharmacists could provide training around this subject. This will probably be received well in the pharmacy profession as many pharmacists (more than $60 \%$ ) in the UK, Indian and South African studies on this subject matter have indicated that they would like to play a more active role in the recognition and management of oral health conditions (Gilbert 1998b:442), but are hesitant due to lack of adequate knowledge on this subject matter. These pharmacists have indicated that they would be keen to learn more about oral health conditions that are applicable to their practice as it would improve the service they provide to the public (Gilbert 1998b:442; Maunder \& Laundes 2005:219; Priya et al. 2008:104).

\section{Conclusion}

The responsibility of disease detection and prevention lies with all health professionals. It is, therefore, important for each health professional to be trained properly in the detection and management of illnesses that they are most likely to encounter. The findings of this study entrenched the position of the pharmacist within the primary healthcare approach. They are approached on a regular basis for oral health advice. They are approached frequently for symptomatic relief of toothache and dental abscess, so are well situated in the healthcare profession to give oral health advice to prevent the future occurrence of caries. The most common oral complaints encountered were oral ulcers and oral thrush. Pharmacists could therefore play a key role in the early detection of HIV, other STIs and oral cancer, as well as various other serious conditions. In this study, SES and metropolitan location did not influence how often patients sought advice and/ or medication for oral health issues, nor the type of oral healthcare advice sought. In light of these findings, training on common oral health conditions should be considered for inclusion in undergraduate pharmacy curricula as well as continuous professional development activities.

\section{Acknowledgements}

I would like to thank Anna Strebel from the Mellon Mentorship programme at the University of Cape Town for her input and guidance, the Department of Community Dentistry at the University of the Western Cape for supporting and funding this project and the reviewers of this paper for their helpful comments.

\section{Competing interests}

The authors declare that they have no financial or personal relationship(s) which may have inappropriately influenced them in writing this article.

\section{Authors' contributions}

F.A. (Faculty of Dentistry, University of the Western Cape) was responsible for the entire project, namely, research design, methodology, data collection, data capturing and analysis and conceptual contributions. N.M. (Faculty of Dentistry, University of the Western Cape) contributed to the research design and methodology and made conceptual contributions. N.B. (School of Pharmacy, University of the Western Cape) contributed to the research design and methodology and made conceptual contributions.

\section{References}

Ambler, C., 1996, '46th Annual General Meeting of the South African Association of community pharmacists: Address to the Pharmaceutical Society General Meeting by SAACP President', South African Pharmaceutical Journal 63, 298-300.

Akpan, A. \& Morgan, R., 2002, 'Oral candidiasis', Postgraduate Medical Journa 78(922), 455-459. http://dx.doi.org/10.1136/pmj.78.922.455, PMid:12185216, PMCid:1742467 
Amien, F., Gordon, N.A., Yasin-Harneker, S., Lalloo, R., Myburgh, N. \& Simpson K.R. 2004, 'Dental caries and social class in a Western Cape population', Journal of Dental Research 84 (special issue B), abstract number 52203, viewed 26 August 2011, from Research 84 (special issue

Arendorf, T.M. \& Holmes, H., 1999, 'Are the Oral Manifestations Associated with HIV Infection Really Relevant to the Practising South African Dentist? A comparative analysis of oral HIV studies in South Africa', South African Dental Journal 54(12), 631-635.

Arendorf, T.M., Bredekamp, B., Cloete, C. \& Stephen, L.X.G., 1999, 'Oral soft-tissue manifestations as presenting symptom/sign of HIV infection', South African Dental Journal 54(12), 602-604.

Ayo-Yusuf, O.A. \& Ayo-Yusuf, I.J., 2008, 'Association of tooth loss with hypertension', South African Medical Journal 98(5), 381-385.

Beney, J., Bero, L.A. \& Bond, C.M., 2000, 'Expanding the roles of outpatient pharmacists: Effects on health services utilisation, costs and patient outcomes', viewed 28 June 2006, from http://onlinelibrary.wiley.com/doi/10.1002/14651858.CD000336/full

Berzborn, S., 2007, 'The Household Economy of Pastoralists and Wage-Labourers in the Richtersveld, South Africa', Journal of Arid Environments 70(4), 672-685. http:// Richtersveld, South Africa', Journal of Arid
dx.doi.org/10.1016/j.jaridenv.2006.09.011

Bhorat, H. \& Shaikh, N., 2004, 'Poverty and labour market markers of HIV+ households: an exploratory methodological analysis', Working Paper 04/083, Development Policy Research Unit, University of Cape Town.

Bradshaw, D., Norman, R., Pieterse, D., Levitt, N.S. \& the South African Comparative Risk Assessment Collaborating Group, 2007, 'Estimating the burden of disease attributable to diabetes in South Africa in 2000', South African Medical Journal 97(7), 700-706.

Case, A., 2001, 'Does money protect health status? Evidence from South African pensions', NBER Working Paper 8495, in D. Wise (ed.), Perspectives in the economics of ageing, pp. 287-311, University of Chicago Press, Chicago.

Chankanka, O., Cavanaugh, J.E., Levy, S.M., Marshall, T.A., Warren, J.J., Broffitt, B. \& Kolker, J.L., 2011, 'Longitudinal associations between children's dental caries and risk factors', Journal of Public Health Dentistry 71(4), 289-300. http://dx.doi. org/10.1111/j.1752-7325.2011.00271.x, PMid:22320287

Chestnutt, I.G., Taylor, M.M. \& Mallinson, E.J.H., 1998, 'The provision of dental and oral health advice by community pharmacists', British Dental Journal 184(11) 532-534. http://dx.doi.org/10.1038/sj.bdj.4809690, PMid:9682545

Cohen, L.A. \& Manski, R.J., 2006, 'Visits to non-dentist health care providers for dental problems', Family Medicine 38(8), 556-564.

Department of Health, Medical Research Council \& OrcMacro, 2007, South Africa. Demographic and Health Survey 2003, Department of Health, Pretoria.

Dickinson, C., Howlett, J.A. \& Bulman, J.S., 1995, 'The role of the community pharmacis as a dental health adviser', Community Dental Health 12(4), 235-237.

Domínguez-Berjón, F., Borrell, C., Rodríguez-Sanz, M. \& Pastor V., 2006, 'The usefulness of area-based socioeconomic measures to monitor social inequalities in health in southern Europe', The European Journal of Public Health 16(1), 54-61. http:// dx.doi.org/10.1093/eurpub/cki069, PMid:16093303

Eighty20., 2006, 'Average annual household income data of residential areas in the Western Cape Province for 2006', Excel spreadsheet.

Ferro, R., Besostri, A., Olivieri, A., Stellini, E., Denotti, G. \& Campus, G., 2012, 'Caries experience in 14-year-olds from Northeast Italy. Is socioeconomic-status (SES) still a risk factor?', European Journal of Paediatric Dentistry 13(1), 46-52.

Gilbert, L., 1997. 'Pharmacist as the "Poor Man's Doctor"', International Pharmacy Journal 11(4), 100-102.

Gilbert, L., 1998a, 'Community pharmacy in South Africa: A changing profession in a society in transition', Health and Place 4(3), 273-285. http://dx.doi.org/10.1016/ S1353-8292(98)00020-3

Gilbert, L., 1998b, 'The role of the community pharmacist as an oral health adviser An exploratory study of community pharmacists in Johannesburg, South Africa', Journal of the South African Dental Association 53(8), 439-443.

Gilbert, L., 1998c. 'Pharmacy's attempts to extend its roles: A case study in South Africa', Social Science and Medicine 47(2), 153-164. http://dx.doi.org/10.1016/S02779536(98)00022-7

Health Protection Agency, 2011, 'HIV in the United Kingdom: 2011 report', viewed 20 April 2012, from www.hpa.org.uk/webw/HPAweb\&HPAwebStandard/HPAweb_C/ 1317131679504

Health Systems Trust, 2007, 'Asthma prevalence (per 1000 )', viewed 18 December 2012, from http://indicators.hst.org.za/healthstats/269/data

Hirschowitz, R., 2000, Measuring poverty in South Africa. Statistics South Africa, Pretoria.

Hobdell, M.H., Oliviera, E.R., Bautista, R., Myburgh, N.G., Lalloo, R., Narendran, S. \& Johnson, N.W., 2003, 'Oral diseases and socio-economic status (SES)', British Dental Journal 194(2), 91-96. http://dx.doi.org/10.1038/sj.bdj.4809882, PMid:12577077

Katzenellenbogen, J.M. \& Joubert, G., 2007, 'Data collection and measurement', in G. Joubert, R. Erlich, J.M. Katzenellenbogen \& S.S. Abdool Karim (eds.), Epidemiology: manual for South Africa, 2nd edn., pp. 106-122, Oxford University Press, Cape Town.

Keller, G. \& Warrack, B. (eds.), 2000, Statistics for Management and Economics, 5th edn., Duxbury, Massachusetts.

Lalloo, R., Myburgh, N.G., Smith, M.J. \& Solanki, G.C., 2004, 'Access to health care in South Africa - the influence of race and class', South African Medical Journal 94(8), 639-642.

Lang, N.P., Schätzle, M.A. \& Loë, H., 2009, 'Gingivitis as a risk factor in periodontal disease', Journal of Clinical Periodontology 36 (suppl. 10), 3-8. http://dx.doi.org/10.1111/ j.1600-051X.2009.01415.x, PMid:19432625
Lindelow, M., 2006. 'Sometimes more equal than others: How health inequalities depend on the choice of welfare factor', Health Economics 15(3), 263-279. http:// depend on the choice of welfare factor, Health
dx.do.1002/hec.1058, PMid:16259049

Lombard, J.C., 1991, 'The role of the pharmacist in primary health care', CHASA, Journal of Comprehensive Health 2(2), 79-80.

López-Martínez, R., 2010, 'Candidosis, a new challenge', Clinics in Dermatology 28(2), 178-184. http://dx.doi.org/10.1016/j.clindermatol.2009.12.014, PMid:20347660

Lu, H.X., Wong, M.C., Lo, E.C. \& McGrath, C., 2011, 'Trends in oral health from childhood to early adulthood: A life course approach', Community Dentistry and Oral Epidemiology 39(4), 352-360. http://dx.doi.org/10.1111/j.1600-0528.2011.00611.x PMid:21362012

Maunder, P.E.V. \& Landes, D.P., 2005, 'An evaluation of the role played by community pharmacies in oral healthcare situated in a primary care trust in the north of England', British Dental Journal 199, 219-223. http://dx.doi.org/10.1038/sj.bdj.4812614 PMid:16127405

McDonald, S., Piesse, J. \& Van Zyl, J., 2000, 'Exploring the distribution of household income in South Africa', South African Journal of Economics 68(3), 186-203. http://dx.doi.org/10.1111/j.1813-6982.2000.tb01177.x

Myburgh, N.G., Solanki, G.C., Smith, M.J. \& Lalloo, R., 2005, 'Patient satisfaction with health care providers in South Africa: the influences of race and socioeconomic
status', International Journal for Quality in Health Care 17(6), 473-477. http:// status', International Journal for Quality in Health Care
dx.doi.org/10.1093/intqhc/mzi062, PMid:15985504

NHS Information Centre, Dental and Eye Care Team, 2010, Adult Dental Health Survey 2009- First Release, NHS Information Centre for Health and Social Care, United Kingdom, viewed 14 March 2013, from http://www.dhsspsni.gov.uk/ adultdentalhealthsurvey_2009_firstrelease.pdf

Office for National Statistics, 2012, 'Cancer incidence and mortality in the United Kingdom, 2008-10', Statistical Bulletin 1, viewed 13 January 2013, from http:// www.ons.gov.uk/ons/dcp171778_289890.pdf

Priya, S., Madan Kumar, P.D. \& Ramachandran, S., 2008, 'Knowledge and attitudes of pharmacists regarding oral health care and oral hygiene products in Chennai city', Indian Journal of Dental Research 19(2), 104-108. http://dx.doi.org/10.4103/09709290.40462, PMid:18445925

Rogers, A., Hassell, K., Noyce, P. \& Harris, J., 1998, 'Advice-giving in community pharmacy: Variations between pharmacies and different locations', Health \& Place 4(4), 365-373. http://dx.doi.org/10.1016/S1353-8292(98)00031-8

Russell, C.A., Elia, M., 2008, 'Nutrition screening survey in the UK in 2007', viewed 20 November 2012, from http://www.bapen.org.uk/pdfs/nsw/nsw07_report.pdf

Scully, C. \& Felix, D.H., 2005, 'Oral medicine - Update for the dental practitioner. Aphthous and other common ulcers', British Dental Journal 199, 259-264. http:// dx.doi.org/10.1038/sj.bdj.4812649, PMid:16155535

Shaw, J.E., Sicree, R.A. \& Zimmet, P.Z., 2010, 'Global estimates of the prevalence of diabetes for 2010 and 2030', Diabetes Research and Clinical Practice 87(1), 4-14. diabetes for 2010 and 2030', Diabetes Research and Clinical Practice
http://dx.doi.org/10.1016/j.diabres.2009.10.007, PMid:19896746

Sello, D.A., Serfontein, J.H.P., Lubbe, M.S. \& Dambisya, Y.M., 2012, 'Factors influencing access to pharmaceutical services in underserviced areas of the West Rand District, Gauteng Province, South Africa', Health SA Gesondheid 17(1), Art.\#609, 8 pages.

Simpson, C.R. \& Sheikh, A., 2010, 'Trends in the epidemiology of asthma in England: a national study of 333,294 patients', Journal of the Royal Society of Medicine 103(3), 98-106. http://dx.doi.org/10.1258/jrsm.2009.090348, PMid:20200181, PMCid:3072257

South African Pharmacy Council, 2012, Rules relating to the services for which a pharmacist may levy a fee and guidelines for levying such a fee or fees, Board Notice 33 of 2012, South African Government Gazette no. 35095, viewed 07 Decembe 2012, from http://www.doh.gov.za/docs/notices/2012/notice33.pdf

Smith, F., 2002, Research Methods in Pharmacy Practice, Pharmaceutical Press, Cornwall.

Tladi, L.S., 2006, 'Poverty and HIV/AIDS in South Africa - an empirical contribution', Journal of Social Aspects of HIV/AIDS Research Alliance 3(1), 369-381. http://dx.doi. org/10.1080/17290376.2006.9724863, PMid:17601019

UNAIDS 2011, 'World AIDS day report', viewed 18 November 2012, from http://www. unaids.org/en/media/unaids/contentassets/documents/unaidspublication/2011/ jc2216_worldaidsday_report_2011_en.pdf

Van Wyk, P.J. \& Van Wyk, C., 2004, 'Oral health in South Africa', International Dental Journal 54 (6 Suppl 1), 373-377. PMid:15631099

Vaske, J.J., Gliner, J.A. \& Morgan, G.A., 2002, 'Communicating judgments about practical significance: Effect size, confidence intervals and odds ratios', Human Dimensions of Wildlife: An International Journal 7(4), 287-300. http://dx.doi. org/10.1080/10871200214752

Ward, K., Butler, N., Mugabo, P., Klausner, J., McFarland, W., Chen, S. \& Schwarcz, S., 2003, 'Provision of syndromic treatment of sexually transmitted infections by community pharmacists: A potentially underutilized HIV prevention strategy', Sexually Transmitted Diseases 30(8), 609-613. http://dx.doi.org/10.1097/01. OLQ.0000079521.04451.10, PMid:12897681

Watson, L., Bond, C. \& Gault, C., 2003, 'A survey of community pharmacists on prevention of HIV and hepatitis B and C: Current practices and attitudes in Grampian', Journal of Public Health Medicine 25(1), 13-18. http://dx.doi.org/10.1093/pubmed/fdg004, PMid:12669912

Western Cape Provincial Health Consultative Workshop Report, 2010, 'A community consultation workshop report: Final', viewed 12 December 2012, from http://www. blacksash.org.za/files/wchconfwfinal.pdf

World Hunger 2012, '2012 World hunger and poverty facts and statistics', viewed 08 December 2012, from http://www.worldhunger.org/articles/Learn/world\%20 hunger\%20facts\%202002.html 